\title{
DRILLING AND CONSTRUCTION DATA FOR WELL 3-3406-13, KAAMOOLOA EXPLORATORY WELL, OAHU, HAWAII
}

U.S. GEOLOGICAL SURVEY

Open-File Report 96-424

Prepared in cooperation with the CITY AND COUNTY OF HONOLULU BOARD OF WATER SUPPLY
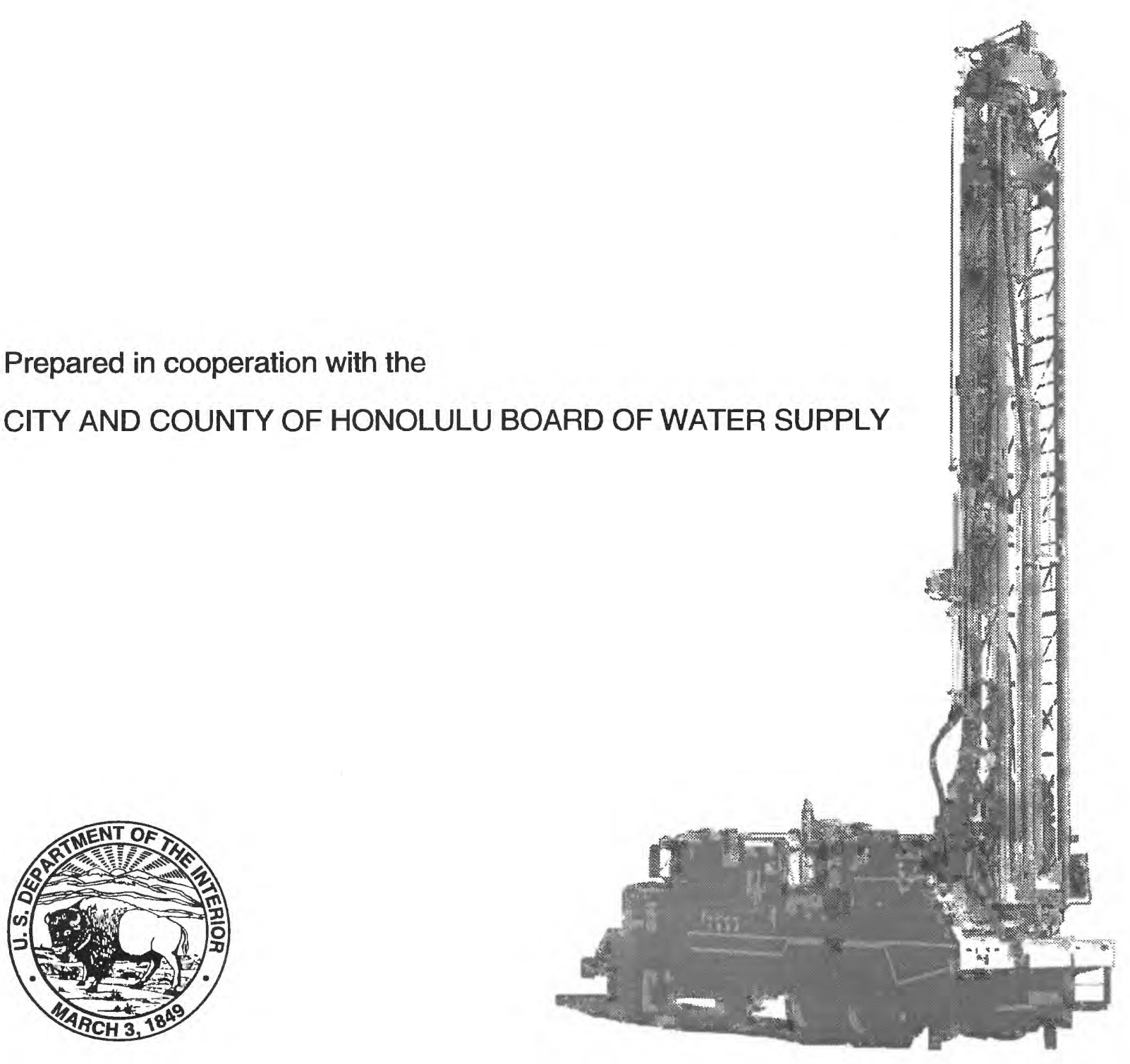


\section{U.S. DEPARTMENT OF THE INTERIOR BRUCE BABBITT, Secretary}

\section{U.S. GEOLOGICAL SURVEY}

Gordon P. Eaton, Director

Any use of trade, product, or firm names in this publication is for descriptive purposes only and does not imply endorsement by the U.S. Government

For sale by the

U.S. Geological Survey

Branch of Information Services

Box 25286

Denver, CO 80225-0286

For additional information write to:

District Chief

U.S. Geological Survey

677 Ala Moana Blvd., Suite 415

Honolulu, HI 96813 


\section{CONTENTS}

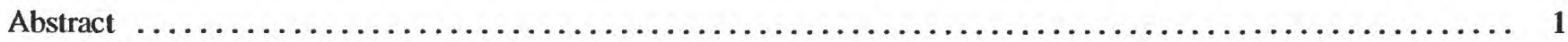

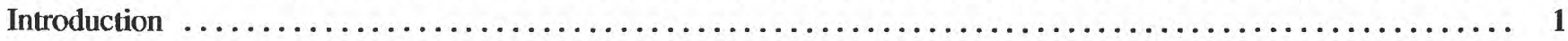

Regional Setting $\ldots \ldots \ldots \ldots \ldots \ldots \ldots \ldots \ldots \ldots \ldots \ldots \ldots \ldots \ldots \ldots \ldots \ldots \ldots \ldots \ldots \ldots \ldots \ldots$

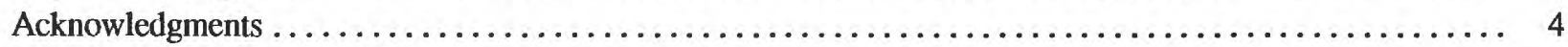

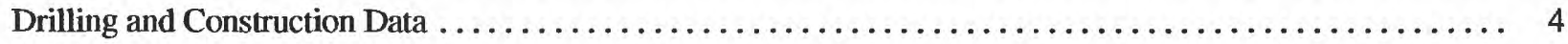

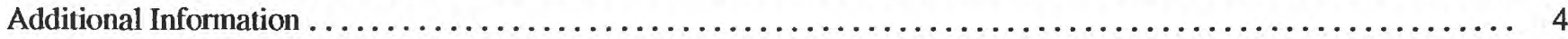

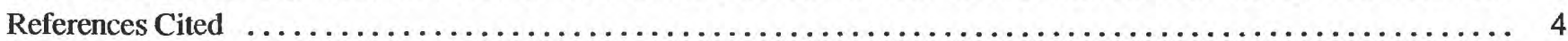

\section{FIGURES}

1-2. Maps showing:

1. Ground-water areas of north-central Oahu and wells drilled during the study, Hawaii ...........

2. Location of the Kaamooloa exploratory well, Oahu, Hawaii . . . . . . . . . . . . . . . . . 3

3. Diagram showing construction details for Kaamooloa exploratory well (State well number 3-3406-13), Oahu, Hawaii

\section{TABLES}

1. Construction data for Kaamooloa exploratory well, Oahu, Hawaii . . . . . . . . . . . . . . . . . . 6

2. Geologic $\log$ for Kaamooloa exploratory well (State well number 3-3406-13), Oahu, Hawaii ............ 6

3. Driller's $\log$ for Kaamooloa exploratory well (State well number 3-3406-13), Oahu, Hawaii ............ 6

4. Construction data for wells drilled during the study, Oahu, Hawaii . . . . . . . . . . . . . . . . . . 7

\section{Conversion Factors}

\begin{tabular}{rcl}
\hline Multiply & By & To obtain \\
\hline foot (ft) & 0.3048 & meter \\
mile (mi) & 1.609 & kilometer \\
inch (in.) & 25.4 & millimeter \\
\hline
\end{tabular}

Elevations in this report are referenced relative to mean sea level. 


\title{
Drilling and Construction Data for Well 3-3406-13, Kaamooloa Exploratory Well, Oahu, Hawaii
}

\author{
By Todd K. Presley and Delwyn S. Oki
}

\section{Abstract}

The Kaamooloa exploratory well (State well number 3-3406-13) was drilled about 1.6 miles south of the town of Haleiwa. The well is on agricultural land in the Waialua ground-water area. The well penetrates about 20 feet into a basalt aquifer to an elevation of -10 feet below mean sea level. Well-construction data, logs of drilling notes, and geologic descriptions for the samples are presented for the well. The well is one of 12 exploratory wells drilled in the north-central Oahu area between July 1993 and May 1994 in cooperation with the Honolulu Board of Water Supply.

\section{INTRODUCTION}

Because of water-supply concerns associated with population increase on the island of Oahu, the Honolulu Board of Water Supply, in cooperation with the U.S. Geological Survey (USGS), conducted a study to assess the availability of ground water in north-central Oahu. This study included drilling 12 exploratory and monitoring wells between July 1993 and May 1994.

This report presents drilling data for the Kaamooloa exploratory well (State well number 33406-13). The well is about $1.6 \mathrm{mi}$ south of the town of Haleiwa, about 4,000 ft south of Weed Circle and about 2,000 ft northeast of Thompson Corner (figs. 1 and 2). The purpose of the Kaamooloa exploratory well is to increase spatial coverage of water-levels in the Waialua ground-water area (Rosenau and others, 1971; Dale, 1978; Hunt, in press) and to provide a water-level observation well for long-term monitoring.

\section{Regional Setting}

The study area is located in north-central Oahu between the crests of the Koolau Range and the Waianae Range (fig. 1). The mountain ranges are the eroded remnants of two shield volcanoes. The mountain ranges are the eroded remnants of two shield volcanoes. The Mokuleia ground-water area lies within the basalt aquifer of the Koolau Volcano. Previous studies (Rosenau and others, 1971; Dale, 1978; Hunt, in press) that describe the physical and geological aspects of the ground-water area are summarized here. The Mokuleia and Waialua ground-water areas are separated by lowpermeability paleosols and saprolite of the Waianae Volcano that lie below the geologic contact between the Waianae and Koolau Volcanoes. The Waialua and Kawailoa ground-water areas are separated by alluvium and weathered basalt in and beneath Anahulu Gulch. Seaward flow of ground water in the Mokuleia and Waialua ground-water areas is impeded by a coastal confining unit that is composed of marine and terrestrial sediment known locally as "caprock." The caprock creates a confined artesian condition at low elevations near the shore. Further inland however, the aquifer is unconfined.

Water levels in the Waialua and Kawailoa groundwater areas are about $12 \mathrm{ft}$ and $4 \mathrm{ft}$, respectively, above mean sea level. Water levels in the Mokuleia groundwater area are about $20 \mathrm{ft}$. Withdrawal from the Waialua, Kawailoa and Mokuleia ground-water areas is primarily for sugarcane irrigation, although there are also several municipal wells and numerous small capacity private wells. Natural ground-water discharge occurs at springs and by subsurface flow through the caprock to the ocean (Rosenau and others, 1971). 


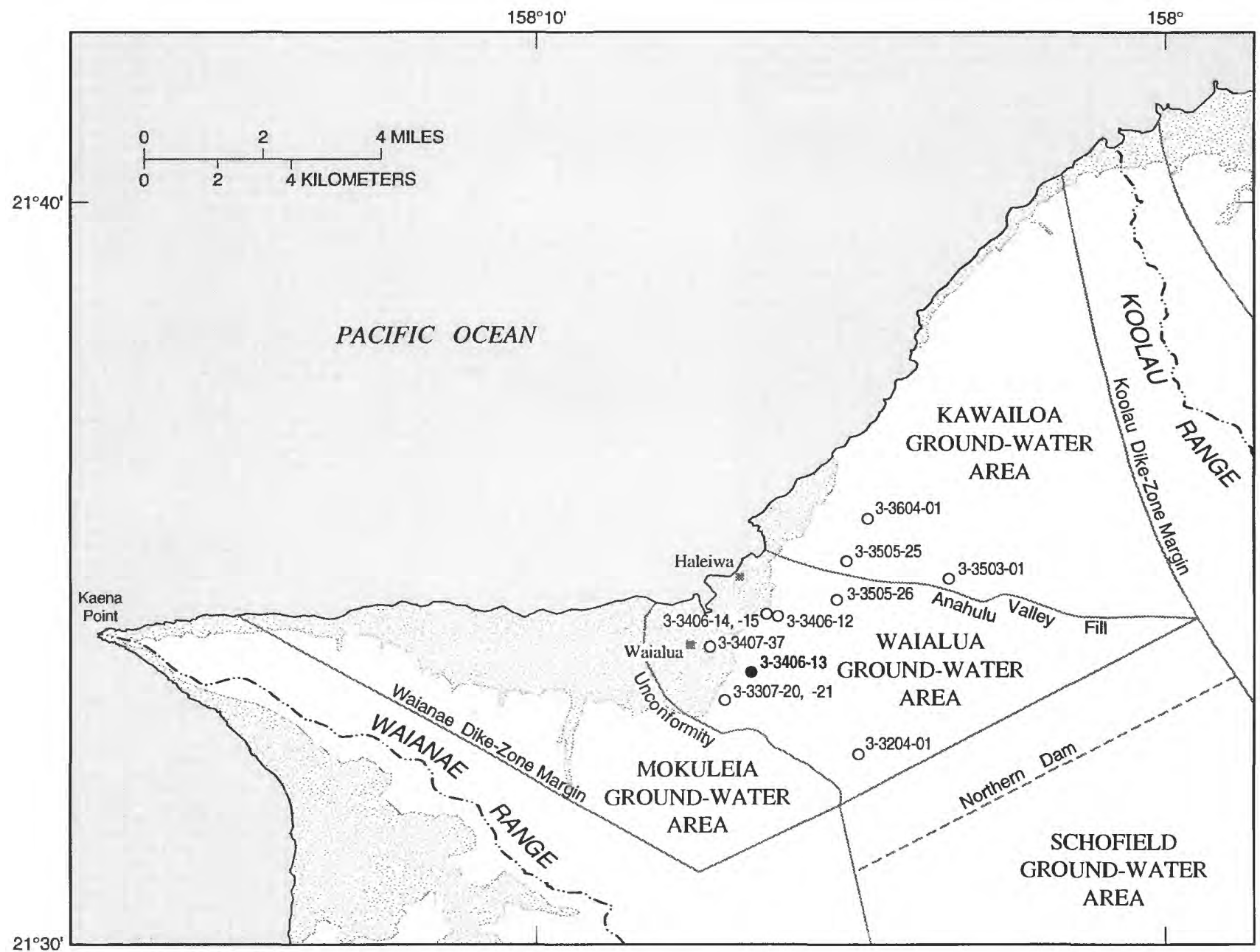

Base modified from U.S. Geological Survey

digital data, 1:24,000, 1983, Albers equal area

projection, standard parallels $21^{\circ} 15^{\circ}$ and $21^{\circ} 45^{\circ}$,

central meridian $157^{\circ} 59^{\prime}$

\section{EXPLANATION}

SEDIMENTARY DEPOSITS (CAPROCK)

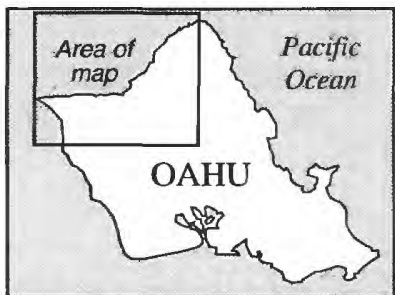

BOUNDARY OF GROUND-WATER AREA

........ TOPOGRAPHIC DIVIDE

3-3406-13 KAAMOOLOA EXPLORATORY WELL

AND STATE WELL NUMBER

3-3406-12 O WELL AND STATE WELL NUMBER

Figure 1. Ground-water areas of north-central Oahu (modified from Hunt, in press) and wells drilled during the study, Hawaii. 


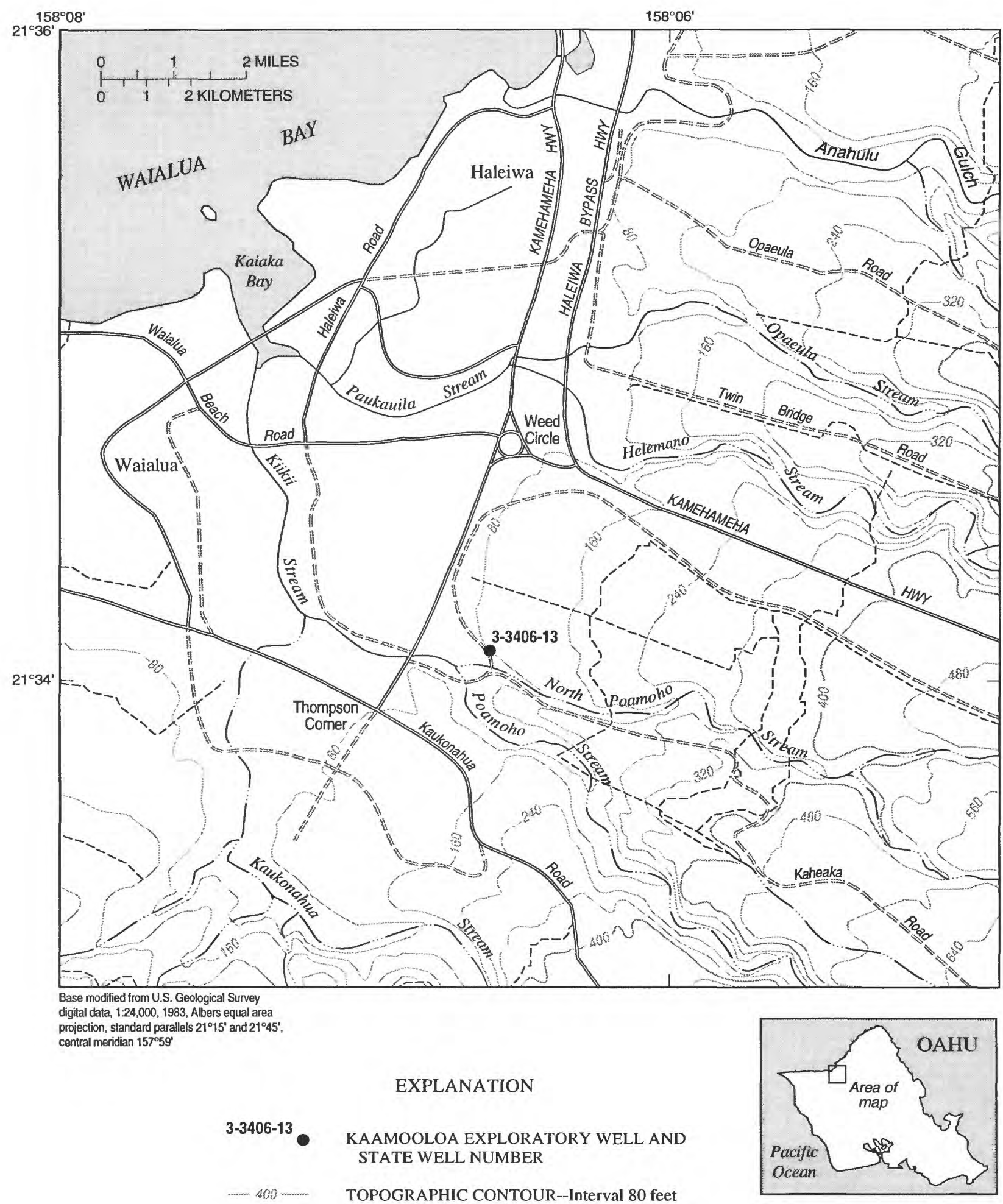

moPOGRAPHIC CONTOUR--Interval $80 \mathrm{feet}$

DITCH

Figure 2. Location of Kaamooloa exploratory well, Oahu, Hawaii. 


\section{Acknowledgments}

The USGS gratefully acknowledges the Waialua Sugar Company for their assistance in identifying and preparing the drill site. The USGS also thanks the Castle and Cooke Land Company for permission to drill on their land.

\section{DRILLING AND CONSTRUCTION DATA}

The Kaamooloa exploratory well (State well number 3-3406-13) is about 2,000 ft northeast of Thompson Corner along a sugarcane plantation road. Well-construction data is provided in table 1 and construction details are shown in figure 3.

The Kaamooloa exploratory well was drilled using an air-rotary system with flush-jointed 4 1/2-in. diameter drill pipe. Drilling foam and polymer were injected into the air-circulation system to assist the removal of drill cuttings and to stabilize the hole. The elevation of the ground surface in the area of the drill site is about 42 $\mathrm{ft}$ above mean sea level. An 7 7/8-in. diameter hole was drilled to an elevation of $10 \mathrm{ft}$ and cased with $30 \mathrm{ft}$ of 6 5/8-in. outside-diameter steel casing. The annular space was grouted with cement to provide a surface seal. A 6 1/4-in. diameter tri-cone tungsten-carbide button bit was then used to drill to an elevation of $-10 \mathrm{ft}$. The well was cased with 4 1/2-in. outside-diameter flush-threaded PVC casing. PVC screen with 0.02-in. horizontal slots was installed through the water column.

Samples of the materials expelled by the circulation system while drilling were collected every $5 \mathrm{ft}$. The geologic $\log$ (geologic descriptions of the recovered samples from drilling) is presented in table 2 , and the driller's $\log$ (driller's observations while drilling) is presented in table 3. From the surface, the bore penetrated about $25 \mathrm{ft}$ of saprolite and $20 \mathrm{ft}$ of weathered basalt.

The measuring point (elevation $42.35 \mathrm{ft}$ ) for waterlevel determination is located on the northwest side of the aluminum well-cap bracket affixed to the top of the $85 / 8$-in. steel surface casing. An additional reference mark (elevation $42.30 \mathrm{ft}$ ) for the well site is located on the top of a stainless steel bolt emplaced into the concrete pad surrounding the well.

\section{ADDITIONAL INFORMATION}

Information for the 12 wells drilled during the north-central Oahu study is listed in table 4. Nine of the wells, including the Kaamooloa exploratory well (State well number 3-3406-13), were drilled in the Waialua ground-water area, and three wells were drilled north of Anahulu Gulch in the Kawailoa ground-water area. Water-level time-series data were collected for all of the wells drilled and for numerous other existing wells as part of the overall monitoring effort for the project (unpublished data in files of the USGS, Honolulu). Data were collected using electronic data loggers coupled to shaft encoder-float systems or pressure transducers.

\section{REFERENCES CITED}

Dale, R.H., 1978, A ground-water inventory of the Waialua basal-water body, island of Oahu, Hawaii: U.S. Geological Survey Open-File Report 78-24, 71 p.

Hunt, C.D. Jr., in press, Geohydrology of the island of Oahu, Hawaii: U.S. Geological Survey Professional Paper 1412-B.

Rosenau, J.C., Lubke, E.R., and Nakahara, R.H., 1971, Water resources of north-central Oahu, Hawaii: U.S. Geological Survey Water-Supply Paper 1899-D, 40 p. 


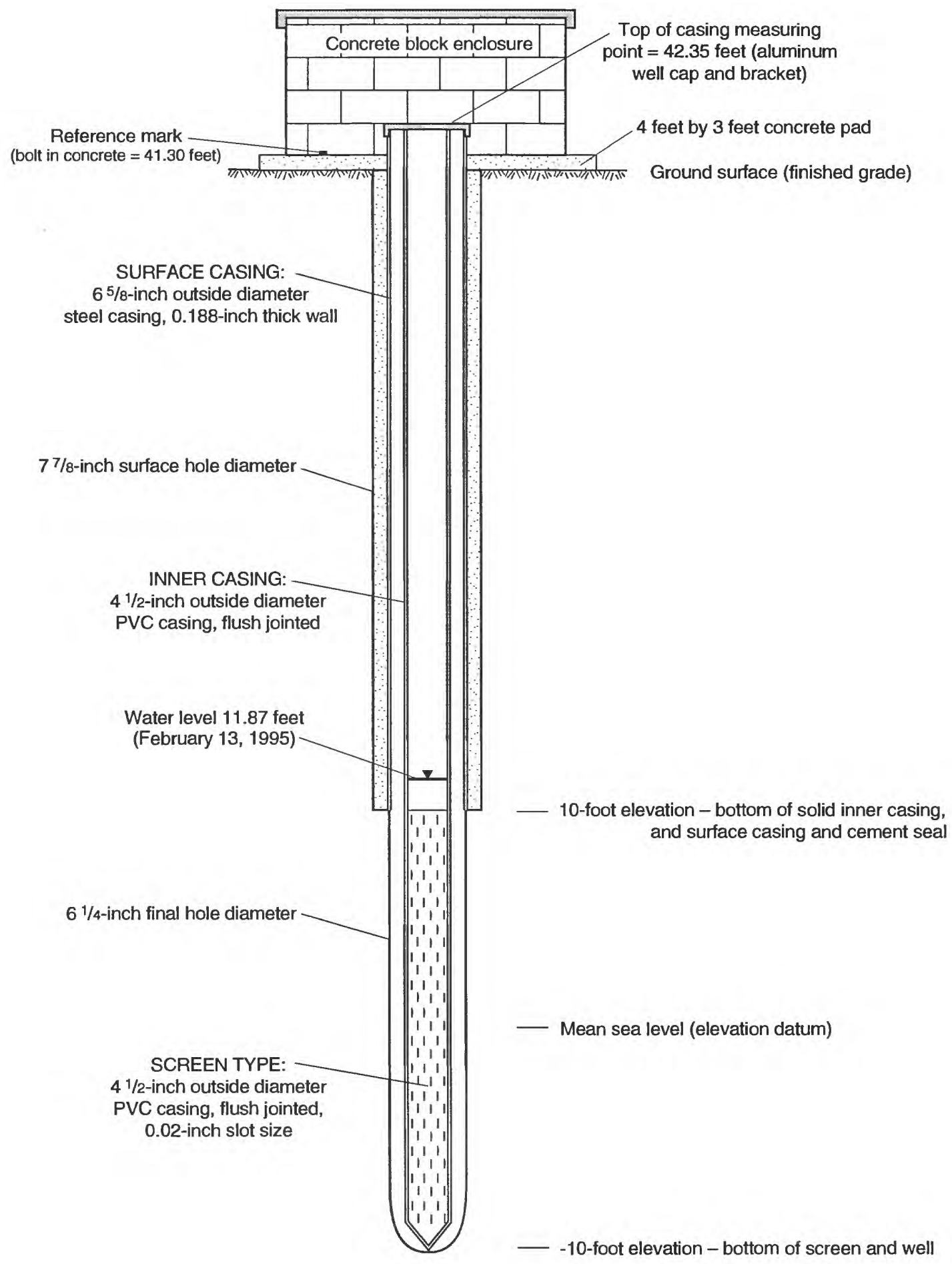

Not to scale

Figure 3. Construction details for Kaamooloa exploratory well (State well number 3-3406-13), Oahu, Hawaii. 
Table 1. Construction data for Kaamooloa exploratory well, Oahu, Hawaii.

[Elevation datum is mean sea level; in., inch; $\mathrm{ft}$, feet; od, outside diameter]

\begin{tabular}{|c|c|}
\hline Well name $\ldots \ldots \ldots \ldots \ldots$ & Kaamooloa exploratory well \\
\hline State well number. . . . . . . . . . . . . . . . . & $3-3406-13$ \\
\hline Latitude and longitude.$\ldots \ldots \ldots \ldots \ldots \ldots \ldots$ & $21^{\circ} 34^{\prime} 06^{\prime \prime} \mathrm{N}, 158^{\circ} 06^{\prime} 36^{\prime \prime} \mathrm{W}$ \\
\hline Hawaii tax map key number.$\ldots \ldots \ldots \ldots \ldots \ldots$ & $6-5-01-2$ \\
\hline 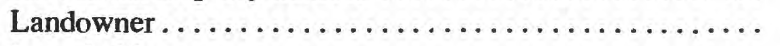 & Castle and Cooke Land Company \\
\hline Leaseholder $\ldots \ldots \ldots \ldots \ldots \ldots \ldots \ldots \ldots \ldots \ldots \ldots \ldots \ldots \ldots \ldots \ldots \ldots \ldots$ & Waialua Sugar Company \\
\hline Well completed.$\ldots \ldots \ldots \ldots \ldots \ldots \ldots \ldots \ldots$ & January 12,1994 \\
\hline Working days to complete $\ldots \ldots \ldots \ldots \ldots \ldots \ldots$ & 4 days \\
\hline 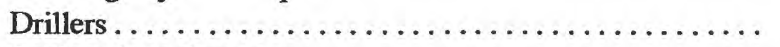 & Fred Thibedeau and Wayne Heick, USGS \\
\hline 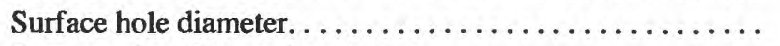 & $77 / 8$ in. \\
\hline Bottom of surface casing elevation $\ldots \ldots \ldots \ldots \ldots \ldots$ & $10 \mathrm{ft}$ \\
\hline Surface casing diameter and type.............. & $65 / 8$-in. od steel, 0.188 -in. wall thickness \\
\hline Final hole diameter. . . . . . . . . . . . . . . . & $61 / 4 \mathrm{in}$. \\
\hline Bottom of well elevation . . . . . . . . . . . . . . & $-10 \mathrm{ft}$ \\
\hline Open interval elevations. . . . . . . . . . . . . . . & $10 \mathrm{ft}$ to $-10 \mathrm{ft}$ \\
\hline Screened interval elevations. . . . . . . . . . . . . . & $10 \mathrm{ft}$ to $-10 \mathrm{ft}$ \\
\hline Inner casing diameter and type $\ldots \ldots \ldots \ldots \ldots \ldots \ldots$ & 4 1/2-in. od PVC, flush-jointed \\
\hline Screen type. . . . . . . . . . . . . . . . . . & 4 1/2-in. od PVC, flush-jointed, 0.02-in. horizontal slots \\
\hline Reference mark elevation (bolt).$\ldots \ldots \ldots \ldots \ldots \ldots$ & $41.30 \mathrm{ft}$ \\
\hline Top of casing measuring point elevation ........... & $42.35 \mathrm{ft}$ (top of aluminum well cap bracket) \\
\hline Water level and date of measurement $\ldots \ldots \ldots \ldots \ldots$ & $11.87 \mathrm{ft}$, February 13, 1995 \\
\hline
\end{tabular}

Table 2. Geologic log for Kaamooloa exploratory well (State well number 3-3406-13), Oahu, Hawaii. [Elevation datum is mean sea level; in., inch; ft, feet; od, outside diameter]

\begin{tabular}{|c|c|c|c|}
\hline $\begin{array}{l}\text { Depth below } \\
\text { grade (feet) }\end{array}$ & $\begin{array}{l}\text { Elevation } \\
\text { (feet) }\end{array}$ & Sample description & Comments \\
\hline 0 to 5 & 41 to 36 & Greyish-red, friable saprolite & \\
\hline 5 to 10 & 36 to 31 & Saprolite; grey, vesicular, hard basalt & Hard basalt, possibly a boulder \\
\hline 10 to 15 & 31 to 26 & Orangish-red saprolite & \\
\hline 15 to 20 & 26 to 21 & Brownish-orange saprolite; few grey rock fragments & \\
\hline 20 to 25 & 21 to 16 & Brownish-orange saprolite; few grey rock fragments & \\
\hline 25 to 30 & 16 to 11 & Grey, nonvesicular, hard basalt & Fresh \\
\hline 30 to 35 & 11 to 6 & Brownish-grey, highly weathered, vesicular basalt & \\
\hline 35 to 40 & 6 to 1 & No sample & \\
\hline 40 to 45 & 1 to -4 & $\begin{array}{l}\text { Orangish, highly oxidized and weathered clinker; some grey, } \\
\text { unweathered, vesicular basalt }\end{array}$ & \\
\hline
\end{tabular}

Table 3. Driller's log for Kaamooloa exploratory well (State well number 3-3406-13), Oahu, Hawaii. [Elevation datum is mean sea level; in., inch; $\mathrm{ft}$, feet; od, outside diameter]

\begin{tabular}{ccl}
\hline $\begin{array}{c}\text { Depth below } \\
\text { grade (feet) }\end{array}$ & $\begin{array}{c}\text { Elevation } \\
\text { (feet) }\end{array}$ & \multicolumn{1}{c}{ Driller's notes } \\
\hline 0 to 33 & 41 to 8 & No information \\
33 to 36 & 8 to 5 & Medium-hard, red-grey rock \\
36 to 40 & 5 to 1 & Soft, red-gray rock \\
40 to 44 & 1 to -3 & Soft to medium, red-grey rock \\
44 to 49 & -3 to -8 & Medium-hard to soft grey-red rock \\
49 to 51 & -8 to -10 & Medium-soft to medium-hard gray rock \\
\hline
\end{tabular}




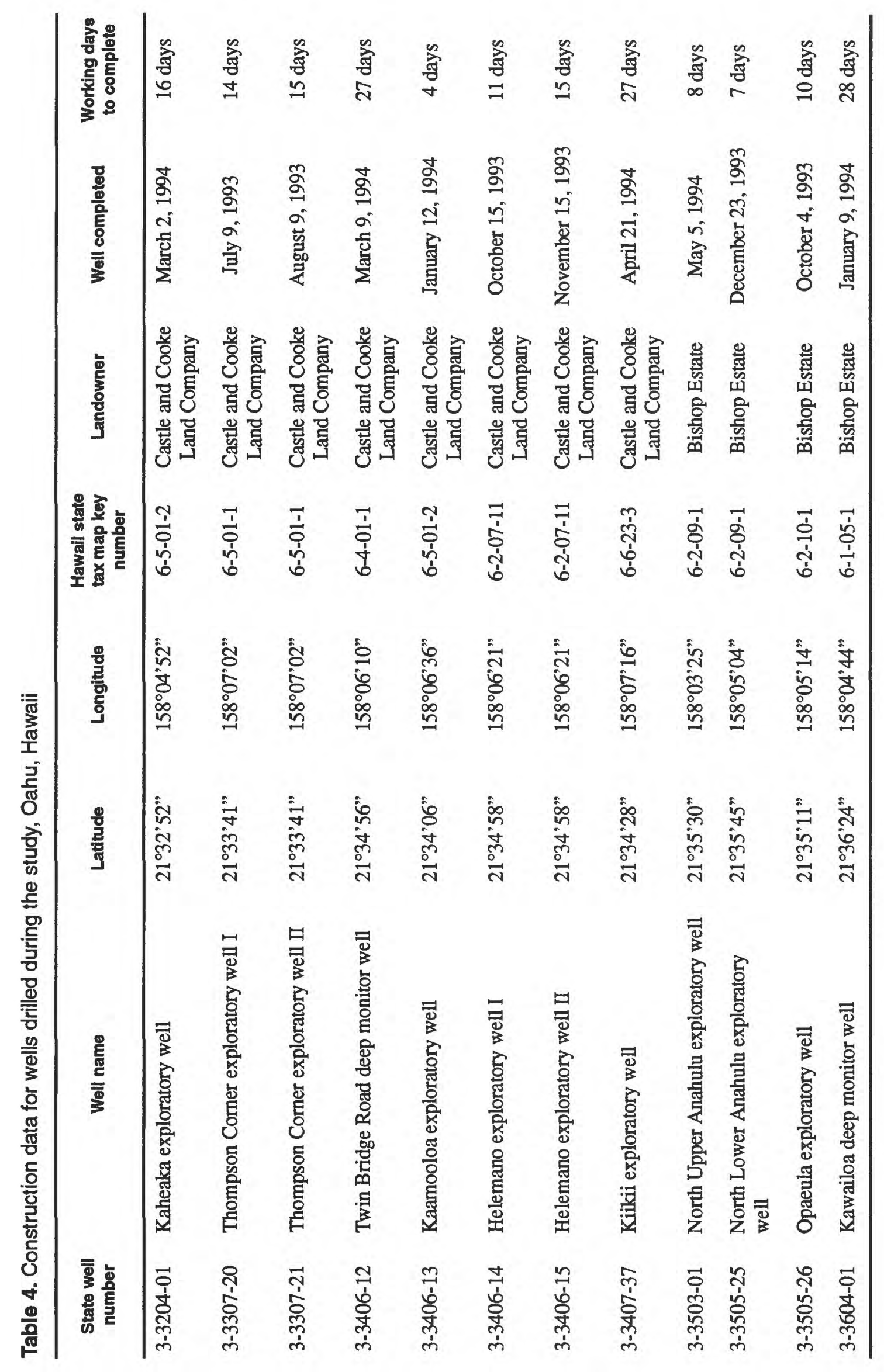




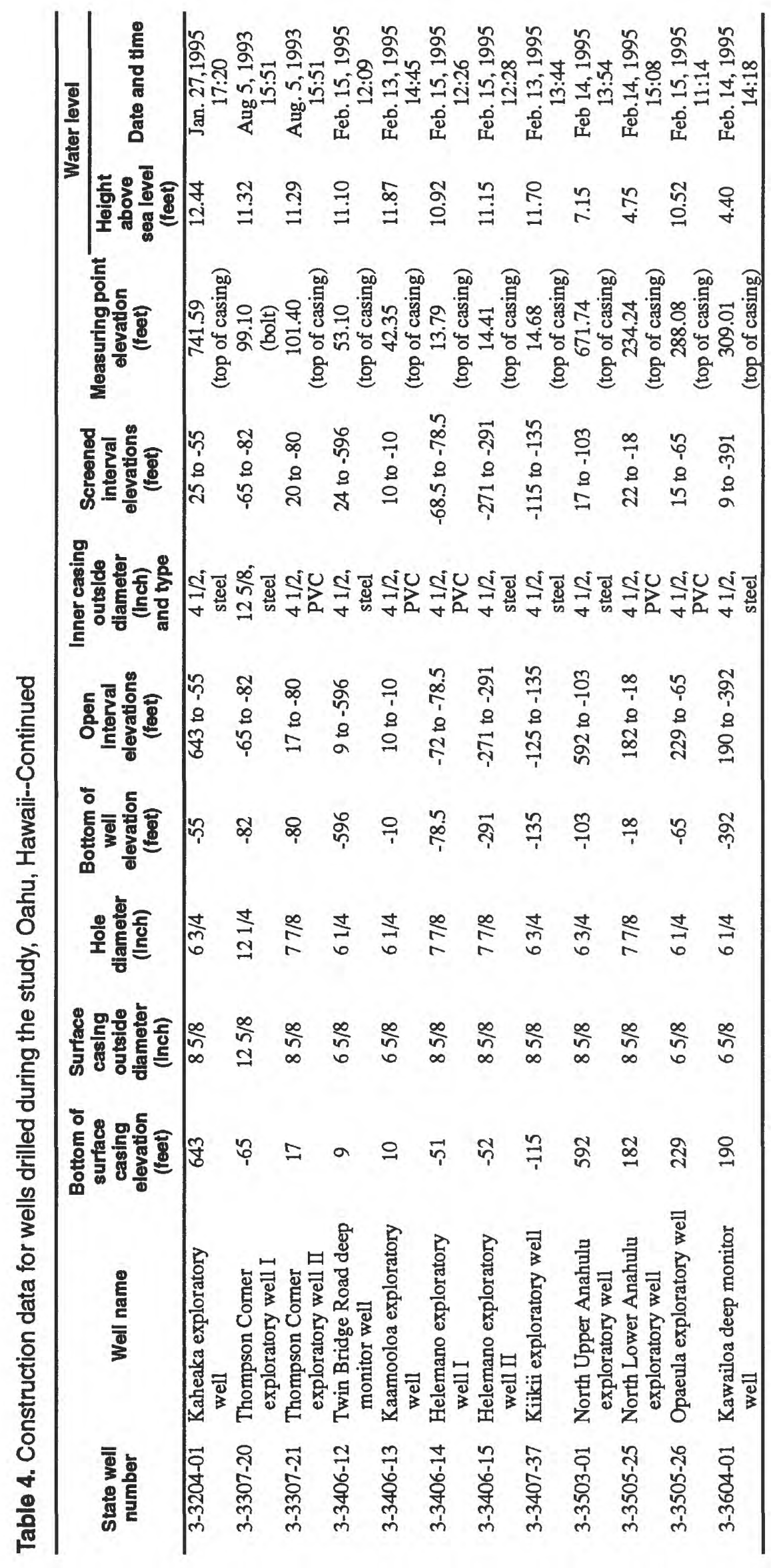

